\title{
ISO CLUSTER CLASSIFIER BY ARCGIS FOR UNSUPERVISED CLASSIFICATION OF THE LANDSAT TM IMAGE OF REYKJAVÍK
}

\section{POLINA LEMENKOVA ${ }^{1 *}$}

${ }^{1}$ Schmidt Institute of Physics of the Earth, Russian Academy of Sciences. Department of Natural Disasters, Anthropogenic Hazards and Seismicity of the Earth. Laboratory of Regional Geophysics and Natural Disasters. Moscow, Russian Federation

\begin{abstract}
The paper presents the use of the Landsat TM image processed by the ArcGIS Spatial Analyst Tool for environmental mapping of southwestern Iceland, region of Reykjavik. Iceland is one of the most special Arctic regions with unique flora and landscapes. Its environment is presented by vulnerable ecosystems of highlands where vegetation is affected by climate, human or geologic factors: overgrazing, volcanism, annual temperature change. Therefore, mapping land cover types in Iceland contribute to the nature conservation, sustainable development and environmental monitoring purposes. This paper starts by review of the current trends in remote sensing, the importance of Landsat TM imagery for environmental mapping in general and Iceland in particular, and the requirements of GIS specifically for satellite image analysis. This is followed by the extended methodological workflow supported by illustrative print screens and technical description of data processing in ArcGIS. The data used in this research include Landsat TM image which was captured using GloVis and processed in ArcGIS. The methodology includes a workflow involving several technical steps of raster data processing in ArcGIS: 1) coordinate projecting, 2) panchromatic sharpening, 3) inspection of raster statistics, 4) spectral bands combination, 5) calculations, 6) unsupervised classification, 7) mapping. The classification was done by clustering technique using ISO Cluster algorithm and Maximum Likelihood Classification. This paper finally presents the results of the ISO Cluster application for Landsat TM image processing and concludes final remarks on the perspectives of environmental mapping based on Landsat TM image processing in ArcGIS.The results of the classification present landscapes divided into eight distinct land cover classes: 1) bare soils; 2) shrubs and smaller trees in the river valleys, urban areas including green spaces; 3) water areas; 4) forests including the Reykjanesfólkvangur National reserve; 5) ice-covered areas, glaciers and cloudy regions; 6) ravine valleys with a sparse type of the vegetation: rowan, alder, heathland, wetland; 7) rocks; 8) mixed areas. The final remarks include the discussion on the development of machine learning methods and opportunities of their technical applications in GIS-based analysis and Earth Observation data processing in ArcGIS, including image analysis and classification, mapping and visualization, machine learning and environmental applications for decision making in forestry and sustainable development.
\end{abstract}

Keywords: Machine learning, Landsat TM, ArcGIS, Cartography.

\section{INTRODUCTION}

The paper presents the use of the Landsat TM image processed by the ArcGIS Spatial Analyst Tool for raster data processing, band calculations and classification. The Landsat TM imagery presents so far one of the most widely used launched programs on satellite based Earth Observation.

The Landsat was launched in July 23, 1972 under the name of Earth Resources Technology Satellite (ERTS-1), and then renamed as Landsat 1 in 1975. Since then the Landsat TM satellite images continues to play an important role in remote sensing domain as an open source reliable data (Woodcock et al., 2008; Zhu et al., 2019). As a result of such successful development, by January 1, 2015 the USGS Landsat archive already contained an impressive data pool of 5.5 million

\footnotetext{
* Corresponding author: pauline.lemenkova@gmail.com GEOGRAPHY, GEOSCIENCE AND ASTRONOMY
}

images with a global coverage and open access availability (Wulder et al., 2016).

Due to its availability and quality, the analysis of the Landsat TM data presents a variety of existing applications (Cao et al., 2020; Lemenkova, 2011, 2015, 2020c, 2020d; Foga et al., 2017; Nagol et al., 2015; Healey et al., 2018; Chowdhury et al., 2021; Homer et al., 2015). With a history of nearly 50 years of continuous global data collection, the Landsat mission has a constant development. Current version include Landsat- 8 which is on-orbit and a Landsat- 9 which is being still under development (Wulder et al., 2019).

Applications of the Landsat TM imagery for remote sensing based mapping are constantly developing due to the actuality of the environmental monitoring in the land planning and policy issues (Flood, 2013). A thorough review summarizing current status of remote sensing of forests and 
forest dynamics using Landsat TM imagery collection is given by Banskota et al. (2014).

A new approach of Landsat TM images processing is introduced by Kennedy et al. (2010) to extract spectral trajectories of land surface change from yearly Landsat timeseries stacks to extract temporal trajectories of spectral data on a pixel-by-pixel basis.

The application of ArcGIS based analysis of the habitat and agricultural crops using Landsat 8 by Maximum Likelihood algorithm of the supervised classification is presented by Herbei \& Sala (2016). Examples of other application of the Landsat TM are given by a variety of papers (Townshend et al., 2012; Lemenkova, 2011, 2014a, 2014b, 2016; Qiu et al., 2019; Goodwin et al., 2013; Vermote et al., 2016) that were considered in this study.

GIS analysis and remote sensing (RS) methods are effective tools for thematic mapping of forest changes enabling better understanding of environmental dynamics (Valjarević et al., 2018). On the other hand, modelling and artificial computer based simulations support GIS research being integral to mapping, graphical visualization and plotting (Schenke \& Lemenkova, 2008; Lindh et al., 2000). Modelling can be applied for the ecological management, mapping, and visualization of crucial information necessary for sustainable environmental prognosis (Vuollekoski et al., 2015). Furthermore, RS applications are applied in predictive modelling, analysis of water quality, and studies on global adaptation to climate change (Tomaszkiewicz et al., 2015).

Using machine learning (ML) algorithms in Remote Sensing (RS) data processing, such as ISO cluster classifier is an effective, accurate and promising tool enabling to perform automatic land cover mapping. A wide variety ofdisciplinesin Earth sciences apply advanced ML methods for data processing (Zhong \& Zhang, 2012; Lindh \& Winter, 2003; Lemenkova, 2019b). These include such domains as landscape studies, geology, environment, remote sensing, marine and ocean research and civil engineering to mention a few (Valjarević et al., 2020; Lindh, 2001, 2004; Lemenkova, 2019c, 2019d). Application of ML for environmental research presents a promising interdisciplinary approach and contributes to the existing regional environmental studies of Iceland (Thórhallsdóttir, 1996; Brombacher et al., 2020).

GIS-based analysis is incorporated into environmental studies for a variety of mapping purposes. For instance, thematic maps depicting the exposure to agricultural pesticides for large areas are produced to alert environmentalists in areas affected by pesticides, and to estimate high-resolution GIS information for pesticides-related health problems (Wan, 2015). Maps based on specific remote sensing data pertaining to various cartographic operations, such as satellite image classification or assessment dynamics of land cover types in various years, are necessary to assist environmentalists in the actual decision making process regarding nature conservation.

Due to the variety of existing GIS software, a selection of suitable tool is necessary to apply its technical functionality to the performed operations in image processing and visualization for environmental analysis. For this reason, this paper used ArcGIS as suitable and powerful tool for image processing and processed Landsat TM image of Reykjavik by a combination of spectral and panchromatic bands for cartographic visualization and presented an ISO cluster classifier classification of the study area to analyse spatial distribution of the land cover types.

\section{STUDY AREA}

\section{Environmental setting}

The study area encompasses the southwestern part of Iceland with its capital Reykjavík (Figure 1). The characteristics of the vulnerable Arctic ecosystems in Arctic Iceland include the resilience of the highland environment to external impact factors including those of climate, human or geologic character (e.g. annual temperature change, overgrazing or local volcanism in the seismically active areas). Among the environmental factors, important conditions are created by geological setting, e.g. volcanism and local hydrogeology which controls the glacial landscape evolution and finally results in the modern topography by sculpturing geomorphic landforms (Robinson et al., 2008).

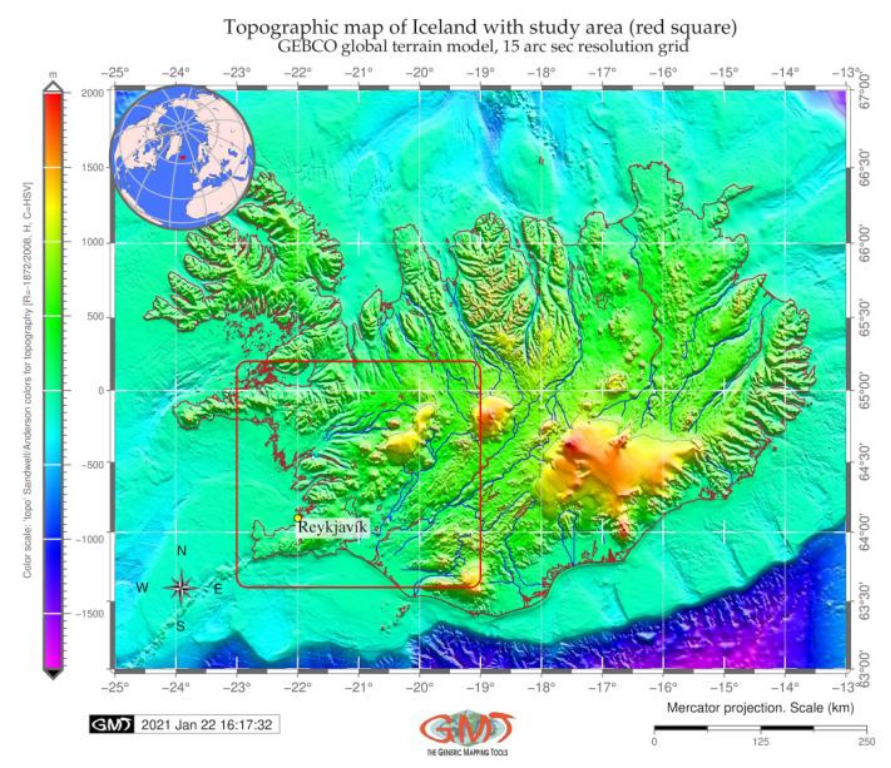

Figure 1. Topographic map of Iceland. Source: author.

The landscapes in Iceland have unique features due to the mixed flora that includes elements from Greenland, Scandinavia and Europe. Therefore, the vegetation of Iceland differs from other part of Arctic and Subarctic (Steindórsson, 1962; Kristinsson, 1986). Mapping such a unique region implies a contribution to nature conservation with regards to the protected areas and or threatened species in Arctic.

The relationship between the relief, geologic strata characteristics and climate factors is finally reflected in the vegetation coverage. Since the geology of Iceland has some specifics due to the volcanic activities (Jakobsson, 1979; Jakobsson et al., 2008), the vegetation has a unique character due to the underdeveloped soil layer. Volcanic conditions in 
the region create special condition of the erosion-prone sandy and volcanic soils where only specific types of plants can exist (Arnalds et al., 2001, 2003).

In turn, the surficial geological processes are reflected in a modern glacial land system context through the glacier dynamics, ablation, ice cover fluctuation under the impact of the climate changes and shaping the glacier terrains (Krüger, 1994). For instance, glaciers and ice sheets largely contribute to the sediment deposition through the processes of erosion and deposition of massive quantities of debris. Besides, subglacial meltwater exerts a control on ice dynamics and sediment transport (Gerrard, 1985; Russell et al., 2006).

\section{Anthropogenic activities}

Apart from the geological and physical geographic factors, the nature of Iceland experiences certain impacts of the anthropogenic origin. More specifically, land use pressure in Iceland is mostly caused by the intense agricultural activities and cattle grazing. Thus, the degree of degradation in Iceland has been assessed in various studies with the aim of the ecosystem change studies (Gísladóttir, 2001; Greipsson, 2012).

Environmental significance of lands using GIS for environmental monitoring plays a crucial role in decision making and land policy (Klaučo et al., 2013a, 2013b). Among other factors, the selection of the advanced tools for data processing and visualization is important. Using GIS analysis of the satellite imagery of the Landsat TM proposes an effective tool for automated data processing especially useful for the regions with harsh climate conditions. This study presents the Landsat TM image processing by using ArcGIS.

\section{METHODOLOGY}

\section{Data Capture and Software}

The Landsat TM scene was taken from the USGS Global Visualization Viewer (GloVis), an online search and order tool for selected remote sensing data (Figure 2).

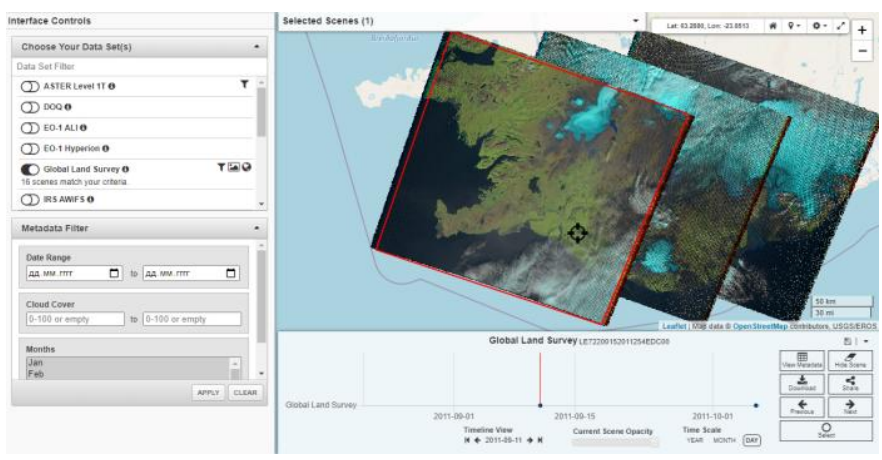

Figure 2. Data capture through the GloVis repository.

The geographic map of the study area (Figure 1) was plotted using the GMT scripting cartographic toolset (Wessel \& Smith, 1995) using GEBCO high-resolution raster map (GEBCO Compilation Group, 2020) by existing methods of GMT (Lemenkova, 2019a, 2020a, 2020b, 2020c) consisting in scripting approach in cartographic visualization. The main cartographic workflow was performed in an ArcGIS, a widely used GIS in geosciences (Suetova et al., 2005a, 2005b; Klaučo et al., 2014, 2017).

\section{Data Preprocessing}

Before the image processing, a cartographic coordinate re-projection was performed (Figure 3). The World Geodetic SystemW GS-1984 Zone 27 was changed to the local GCS_Reykjavik_1900 EPSG:4657 with accuracy $10.0 \mathrm{~m}$, which has following WGS 84 bounds: $-24.66^{\circ} \mathrm{W}, 63.34 \mathrm{~N}$ to $13.38^{\circ} \mathrm{W}, 66.59 \mathrm{~N}$ and a center coordinate $-19.02378948^{\circ}$ $64.96335686^{\circ}$ which is suitable for mapping of Iceland (Figure $3)$.

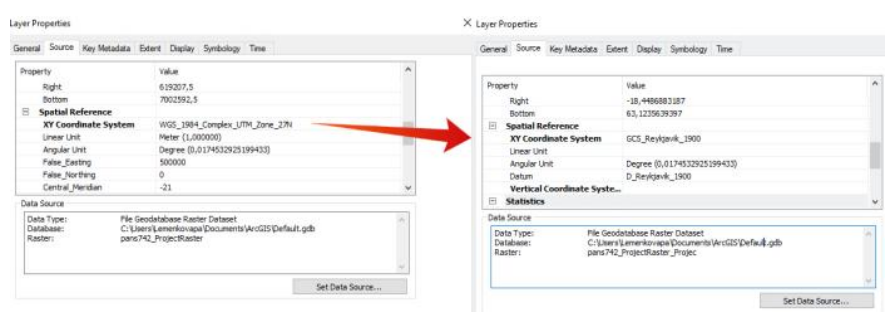

Figure 3. Change of coordinate system WGS84 UTM_27N to GCS_Reykjavik_1900 in ArcGIS.

This coordinate system is maintained by the Landmaelingar Islands (National Survey of Iceland).

Image pan-sharpening

The next step includes a procedure of the pan-sharpening which has been performed using ArcGIS menu with a following path:

ArcToolbox $>$ Data Management Tools $>$ Raster $>$ Raster Processing > Create Pan-sharpened Raster Dataset (Figure 4).

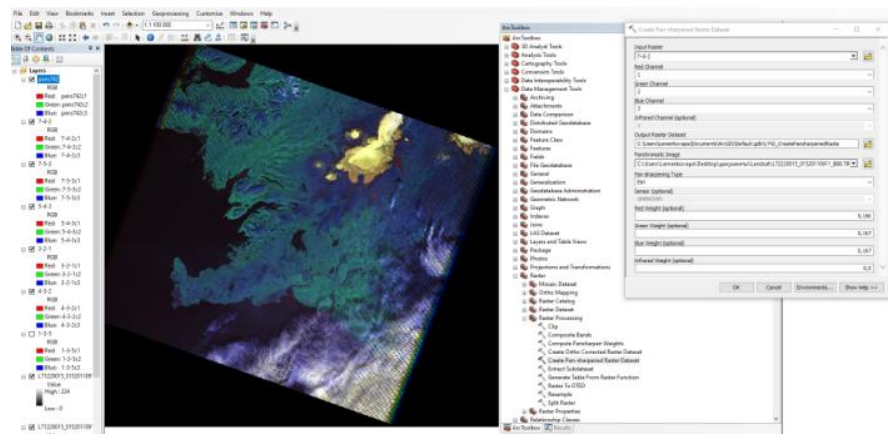

Figure 4. Pan-sharpening Landsat TM by a combination of spectral and panchromatic bands. Source: author.

The pan-sharpening (panchromatic sharpening) of the Landsat TM satellite image follows the principle of taking the best qualities of each band to achieve a better output result.

More specifically, it is a technique that combines the high-resolution panchromatic band with a high level of precision (panchromatic band has a resolution of $15 \mathrm{~m}$ per pixel, which is twice as detailed as the individual spectral bands) with the lower-resolution yet color information of spectral bands (30 $\mathrm{m}$ resolution in visible bands). Such a combination provides a more detailed and precise image, as shown in Figure 4. The pan-sharpening type was selected as ESRI and a band combination is 7-4-2. 
Other parameters for the pan-sharpening include nearest resampling method, and creating pyramids for quicker raster processing. The cartographic coordinate system is PROJCS [WGS-1984 Zone 27N], geographic Transformation NAD_1927_To_NAD_1983_NADCON (North American Datum). These and other technical details were checked up in Compute Pan-sharpen Weights menu, as well as Calculate Statistics and Get Raster Properties menus of Data Management Tools of the ArcGIS.

Hence, the precision was set up as the highest (Figure 4). The raster statistics and properties after the pan-sharpening are checked by the menu of ArcGIS (Figure 5).

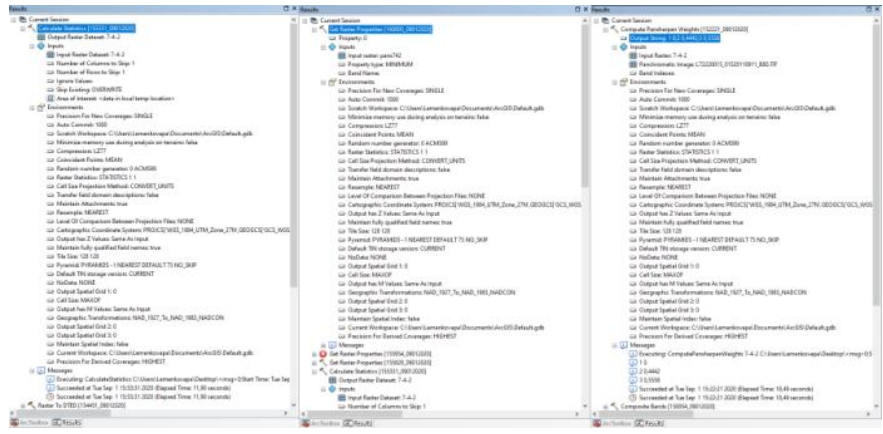

Figure 5. Raster statistics after pan-sharpening.

\section{ISO Cluster Classifier}

The next step included an unsupervised classification by ISO Cluster Classifier using ArcGIS (Figure 6 and 8).

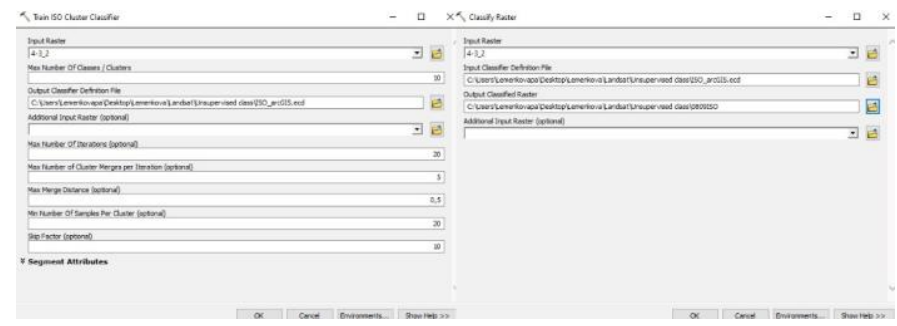

Figure 6. Menu of Spatial Analyst Tools, Segmentation and Classification, ArcGIS. Source: author.

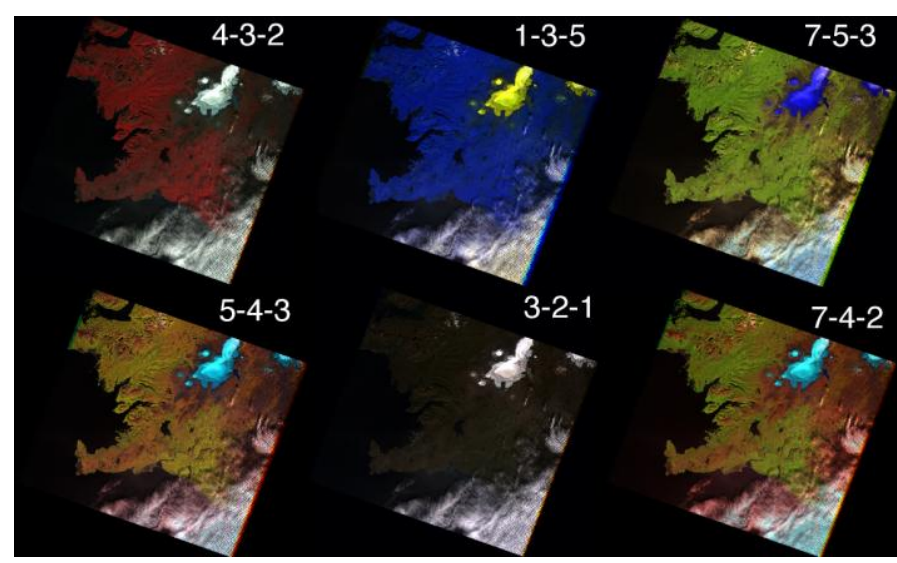

Figure 7. Color composites of the Landsat TM 7 bands in ArcGIS. Source: author.

Various methods of satellite image processing exist and described in the literature (Abburu \& Golla, 2015; Schowengerdt, 2007; Lemenkova, 2013a). Due to the benefits of image classification, it is common for remote sensing analysis to adopt various existing approaches of classification (both supervised and unsupervised) of Landsat TM image. Among the variety of classification methods one should mention the following ones: unsupervised K-mean and ISODATA, random trees, supervised learning methods such as vector machine classifier, maximum likelihood to mention a few.

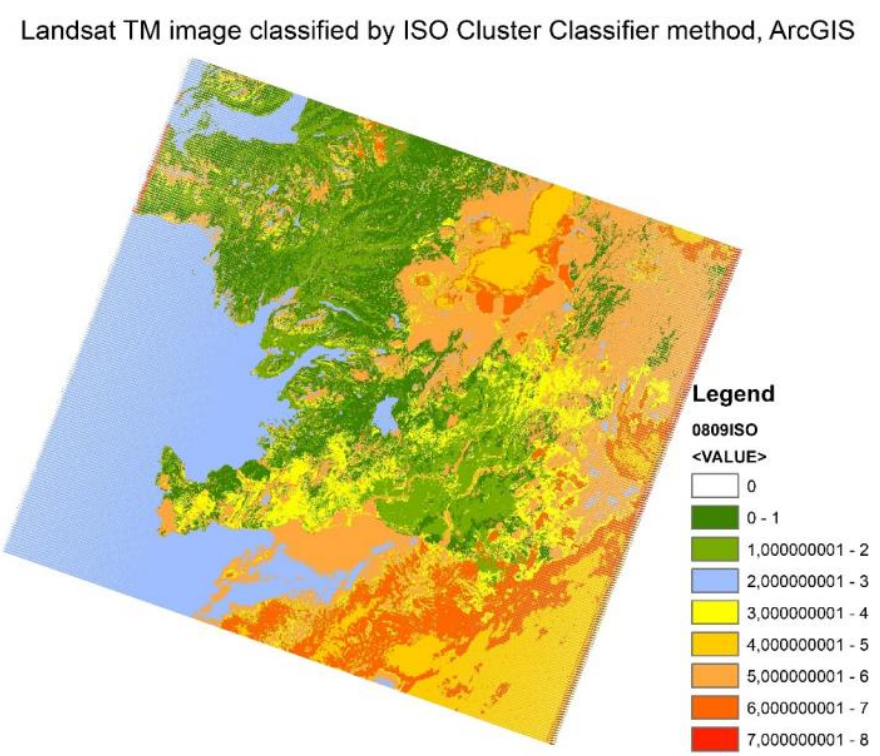

Figure 8. Results of the ISO Cluster Classifier classification, ArcGIS. Source: author.

The ISO Cluster Classifier was selected in this research due to its straightforward and machine-based approach with minimized human intervention. The menu of the selected parameter is presented in Figure 6. First, the Train ISO Cluster Classifier was performed in the selected color composite bands with the created output file ISO_arcGIS.ecd, which is an ESRI classifier definition file (Figure 6, left).

Using this file, the ArcGIS classifies a raster dataset inputs using the generated ecd file which contains all the information to perform an ESRI-supported classification (Figure 6, right). After that, the image was processed using the embedded algorithm of ESRI (Figure 8).

\section{RESULTS AND DISCUSSION}

Image analysis

The unsupervised classification made using ArcGIS used archived, high-resolution pan-sharpened Landsat TM 7 satellite image to classify and distinguish where vegetated habitats, urban areas, and bare soils exist and if vegetation areas can be separated into several sub-classes. The research focused on the region bordered by $18^{\circ}-24^{\circ} \mathrm{W}, 63^{\circ}-65.2^{\circ} \mathrm{N}$ and includes Reykjanesfólkvangur National reserve with various land cover types that include volcanic products (lava formations and crater lakes), bird cliffs and geothermic fields. The impact of volcanism was detected in the origfin of dust 
sources in the soils of Icelands, which includes basaltic volcanic glass (Arnalds, 2004, 2010).

Another special object includes the Pingvallavatn (Thingvallavatn), a rift valley lake in $21,09^{\circ} \mathrm{W}, 64,11^{\circ} \mathrm{N}$. With a surface of $84 \mathrm{~km}^{2}$ it is the largest natural lake in Iceland of volcanic origin with the greatest depth at $114 \mathrm{~m}$ located near the Thingvellir National Park. The geologic setting includes cracks and faults with the Almannagjá ravine as the largest. North of Reykjavik there is a 30-km long Hvalfjörour fjord which was clearly detected on the image together with other water areas.

\section{Interpretation of color compositions}

The unsupervised classification

The original Landsat TM image was processed and color composites were created using various band combinations (Figure 7). A variety of band combinations provide additional information on the objects that can be highlighted by the correct colors.

When interpreting the results of the land cover classification it can be discovered that classifying spectral reflectance of pixels by the machine learning made fewer errors comprehending land cover types and distinguishing betwen landscape classes than it did with human-based GIS classification (e.g. supervised learning methods). Thus, as can be seen in Figure 7, the color composite 4-3-2 (upper row, left in Figure 7) provides a false color composite suitable for detecting vegetation coverage.

- An effective composition is achieved by the bands 1-35 (upper row, center in Figure 7). that gives the bright yellow color for the ice-covered regions, which can be suitable for glaciological studies, e.g. assessment of glacier retreats by comparison of ice coverage in various dates. Such a bright highlighting of glaciers can be distinguished on the image and processed further by methods of image classification.

- The 'natural with atmospheric removal' is achieved by combination of 7-5-3 (upper row, right in Figure 7).

- The false color composite (Figure 7) uses a band combination 4-3-2 where the vegetation performs in bright crimson red colors.

- The color infrared (vegetation) composition is achieved by 5-4-3 bands (lower row, left in Figure 7).

- The behavior similar to this band composition can be seen on a combination 7-4-2 (lower row, right in Figure 7 ). The difference between the both consists in brighter and greener (more natural-looking) vegetation in the 7 4-2 composition.

- The combination of natural colors is achieved by the bands of 3-2-1 (lower row, center in Figure 7).

\section{Unsupervised classification}

The unsupervised classification based on the color composites does not require creating training points and is a fully machine learning approach (Figure 8). The clustering algorithms here was used to build training sites for a without using field survey data. The advantage of the Iso Cluster approach consists in its combination of the functionalities of the Iso Cluster and Maximum Likelihood Classification. The output classified raster implies creating of the signature file.

As evident in Figure 8 (Results of the ISO Cluster Classifier classification), a high degree of distinguisheability in classes of land cover types used in a landscape context reflects spectral reflectance properties of various surfaces on Earth. The ISO Cluster unsupervised classifier is based on the nine selected classes of which eights classes represent 'land cover types' and one class shows technical 'no values' for the rest of the pixels (this corresponds to the technical noises on the images).

This study considered published literature on remote sensing and environmental mapping that described the standardised approaches to land cover types detection and interpreting the results. The resulting 8 classes (plus the "no data' class colored by white areas) are well associated with the land cover types distributed over the area of Reykjavik and surroundings (Figure 8).

1. The first class (dark green colors) is classified as bare soils.

2. The second class (light green colors) shows shrubs and smaller trees mostly located in the river valleys, as well as urban areas including green spaces.

3. The third class (blue color) clearly detected water areas.

4. The forth class (yellow colors) shows forest areas: for instance, the Reykjanesfólkvangur National reserve is included in this class.

5. The fifth class (sandy beige color) means ice-covered areas and cloudy regions on the image. This class also includes some misclassified types of vegetation and water areas with high spectral reflectance that can be assigned to these classes.

6. The sixth class (beige color) shows the ravine valleys with a special, mostly sparse type of the vegetation distributed over the study area: rowan, alder, heathland, wetland and other and other similar types of grasses, e.g. Nootka lupin (Lupinusnootkatensis), distributed due to the limited soil development in Iceland and Nordic climate.

7. The seventh class (orange color) shows bare rocks.

8. The eights class (crimson red color) has a very rare occurrence and mostly shows mixed areas of the land cover types.

The demonstrated benefit of machine learning in ArcGIS based environmental studies is that resulting map is more accurate, objective and independent in terms of interpreting land cover types than when applying human based supervised classification methods for image processing. The study shown that complex and heterogeneous landscapes may be classified with the improved technical options of ArcGIS that include both cartographic and remote sensing functionality available in Arc Toolbox of ArcGIS. 


\section{DISCUSSION}

\section{Perspectives}

In Iceland, vegetation distribution can be qualitatively differentiated and have a wide variety of types. These inlcude rocky landscapes, ice-covered areas, volcanic sands and water bodies. Using spectral data of these land cove types can support environmental monitoring. In contrast, selected land cover types (vegetation types) could not be classified and they are merged with other land cover types due to the spectral reflectance properties similar to these types. This highlights the importance of sufficient information for a better classification. This can includespecial data on forest types and clarity of image with regards to cloudiness.

The study has implications for the monitoring, conservation and management of land cover types in southwestern coastal region of Iceland around Reykjavik and other vegetated habitats. The results presented a map of the land cover types based on the unsupervised classification (a machine learning approach) performed in ArcGIS Desktop 10.7 Spatial Analyst. The study provided a land cover types map with eight machine-separated classes, and a classification framework using a 'Train IDSO Cluster Classifier'. This approach requires no fieldwork neither creating training samples, that is, a fully machine-based classification of the Landsat TM satellite image.

\section{Recommendations}

The dominant vegetation types along the southwestern shores of Iceland can further be selected using the datasets on biogeographical patterns in the native flora of Iceland. In Iceland, there are 438 species in the vascular flora (Kristinsson, 2008; Wasowicz et al., 2014). Computer-based image classification ishighly valuable for environmental mapping of the distribution of the vegetation types.

The distribution of vegetation on the one hand depends on the variety of factors including climatic, topographic, social (urban areas), geomorphological (slope steepness), and geological (bedrock types) variables. On the other hand, vegetation serves as a significant indicator of healthy ecosystem, since it provides essential functions (e.g. habitat) in a complexity of its functioning. Therefore, testing various methods and applications of land cover mapping is crucial and recommended both for the regional development of the environmental protection in Arctic and for the technical testing of ArcGIS functionality in thematic mapping and remote sensing applications.

Core advantages of machine learning methods in remote sensing and GIS over traditional methods - such as the speed of classification with which land cover maps can be generated automatically by the machine, as well as the automated adjustment of distinguishable color palettes of land classes for display in ArcGIS mapping - have been maximized significantly owing to technological changes in GIS development in recent years.

\section{CONCLUSION}

This study assessed the effectiveness of using the Landsat TM image for the automatic classification of the land cover types in Iceland using ArcGIS. The automation in Earth observation studies is based on using machine learning (ML) algorithm of data recognition and processing. The advantages of the automatization in cartographic studies consists in the reduced human-prone errors, increased speed of data processing and correctness of the final output.

The combination of the satellite spectral data from Landsat TM imagery in ArcGIS demonstrated classification of the scenes for environmental monitoring and land policy analysis in high Arctic regions. In addition, the combination of spectral bands effectively demonstrated the possibility of the Landsat TM for highlighting selected objects of interest and detecting land cover types (e.g. ice coverage, land and water areas, agricultural crop fields).

Although visible bands of the Landsat TM have a moderate accuracy $(30 \mathrm{~m})$, the addition of the panchromatic band when combined with other Landsat bands enables to increase the accuracy and resolution of the image through the pan-sharpening, as demonstrated. The paper also showed the workflow of the ArcGIS for projecting coordinates with regard to the study location (GCS_Reykjavik_1900). The ArcGIS is a powerful GIS both for vector and raster data processing. It includes a wide variety of tools for mapping and cartographic analysis.

Selected pixels or small-scale areas can still be misclassified because of the proximity of spectral reflectance properties in objects making difficult to distinguish between various vegetation types. However, the presented approach can detect the most significant spectral signatures, such as land cover types both in urban and in forest-covered areas of the region of Reykjavik. An ISO Cluster approach to classify the image composed of the three spectral bands is a promising approach for land cover types mapping.

Because Iceland is one of the most special Arctic regions with unique flora and landscapes, it presents opportunities for land cover studies based on Landsat TM classifications. Hence, it is important toperform an ArcGIS-based Landsat TM image processing that visualizespresent land cover patterns around Reykjavik and enables monitoring land cover changesin similar research usingseveral Landsat TM scenes.

The present study employed reliable Landsat TM data and ArcGIS methodology to perform an ISO Cluster classification of land cover types in Reykjavik area. This study presented mapping land cover types using ArcGIS by the unsupervised classification approach. The methodology includes several print screens illustrating workflow which can be repeated in similar research in the future. This study contributes both to the regional Arctic studies of Iceland and to the technical testing of the cartographic functionality of ArcGIS with a special focus on remote sensing data. 


\section{ACKNOWLEDGMENTS}

The author thanks the reviewers and editor for the review, critical remarks, suggestions and editing of this manuscript.

\section{REFERENCES}

Abburu, S. \& Golla, S. B. 2015. Satellite Image Classification Methods and Techniques: A Review, International Journal of Computer Applications, 119(8), pp. 20-25. https://doi.org/10.5120/21088-3779

Arnalds, O., Gisladottir, F. \& Sigurjonsson, H. 2001. Sandy deserts of Iceland: an overview, Journal of Arid Environments, $47, \quad$ pp. 359-371. https://doi.org/10.1006/jare.2000.0680

Arnalds, O. \& Barkarson, B. H. 2003. Soil erosion and land use policy in Iceland in relation to sheep grazing and government subsidies, Environmental Science \& Policy, $6(1)$, pp. 105-113. https://doi.org/10.1016/S14629011(02)00115-6

Arnalds, O. 2004. Volcanic soils of Iceland. Catena 56, pp. 3 20. https://doi.org/10.1016/j.catena.2003.10.002

Arnalds, O. 2010. Dust sources and deposition of aeolian materials in Iceland. Icelandic Agricultural Sciences 23(1), pp. 3-21.

Banskota, A., Kayastha, N., Falkowski, M. J., Wulder, M. A., Froese, R. E. \& White, J. C. 2014. Forest Monitoring Using Landsat Time Series Data: A Review. Canadian Journal of Remote Sensing, 40, pp. 362-384. https://doi.org/10.1080/07038992.2014.987376

Brombacher, J., Reiche, J., Dijksma, R. \& Teuling, A. J. 2020. Near-daily discharge estimation in high latitudes from Sentinel-1 and 2: A case study for the Icelandic Pjórsá river, Remote Sensing of Environment, 241, pp. 111684. https://doi.org/10.1016/j.rse.2020.111684

Cao, Z., Ma, R., Duan, H., Pahlevan, N., Melack, J., Shen, M. \& Xue, K. 2020. A machine learning approach to estimate chlorophyll-a from Landsat- 8 measurements in inland lakes, Remote Sensing of Environment, 248, pp. 111974.

Chowdhury, S., Peddle, D. R., Wulder, M. A., Heckbert, S., Shipman, T. C. \& Chao, D. K. 2021. Estimation of landuse/land-cover changes associated with energy footprints and other disturbance agents in the Upper Peace Region of Alberta Canada from 1985 to 2015 using Landsat data, International Journal of Applied Earth Observation and Geoinformation, 94, 102224. https://doi.org/10.1016/j.jag.2020.102224

Flood, N. 2013. Seasonal composite Landsat TM/ETM+ images using the medoid (a multi-dimensional median), Remote Sensing, 5, pp. 6481-6500. https://doi.org/10.3390/rs5126481

Foga, S., Scaramuzza, P. L., Guo, S., Zhu, Z., Dilley, R. D., Beckmann, T., Schmidt, G. L., Dwyer, J. L., Joseph Hughes, M. \& Laue, B. 2017. Cloud detection algorithm comparison and validation for operational Landsat data products. Remote Sensing of Environment, 194, pp. 379390. https://doi.org/10.1016/j.rse.2017.03.026

GEBCO Compilation Group 2020. GEBCO 2020 Grid. https://doi.org/10.5285/a29c5465-b138-234d-e0536c86abc040b9

Gerrard, A. J. 1985. Soil erosion and landscape stability in southern Iceland: a tephrochronological approach. 18 pp. In: K.S. Richards, R.R. Arnett, S. Ellis (eds.). Geomorphology and Soils. 1st Ed. London, Routledge https://doi.org/10.4324/9780429320781

Gísladóttir, G. 2001. Ecological Disturbance and Soil Erosion on Grazing Land in Southwest Iceland, Land Degradation. Springer, pp. 109-126. https://doi.org/10.1007/978-94-0172033-5_7

Goodwin, N. R., Collett, L. J., Denham, R. J., Flood, N. \& Tindall, D. 2013. Cloud and cloud shadow screening across Queensland, Australia: an automated method for Landsat TM/ETM+ time series. Remote Sensing of Environment, 134, pp. 50-65. https://doi.org/10.1016/j.rse.2013.02.019

Greipsson, S. 2012. Catastrophic soil erosion in Iceland: impact of long-term climate change, compounded natural disturbances and human driven landuse changes, Catena, 98, pp. 41-54. https://doi.org/10.1016/j.catena.2012.05.015

Healey, S. P., Cohen, W. B., Yang, Z., Brewer, C. K., Brooks, E. B., Gorelick, N., Hernandez, A. J., Huang, C., Hughes, M. J., Kennedy, R. E., Loveland, T. R., Moisen, G. G., Schroeder, T. A., Stehman, S. V., Vogelmann, J. E., Woodcock, C. E., Yang, L. \& Zhu, Z. 2018. Mapping forest change using stacked generalization: An ensemble approach. Remote Sensing of Environment, 204, 717-728. https://doi.org/10.1016/j.rse.2017.09.029

Herbei, M. \& Sala, F. 2016. Classification of Land and Crops Based on Satellite Images Landsat 8: Case Study SD Timisoara, Bulletin UASVM series Agriculture, 73(1), pp. 29-34. https://doi.org/10.15835/buasvmcn-agr:12007

Homer, C. G., Xian, G., Aldridge, C. L., Meyer, D. K., Loveland, T. R. \& O’Donnell, M. S. 2015. Forecasting sagebrush ecosystem components and greater sage-grouse habitat for 2050: Learning from past climate patterns and Landsat imagery to predict the future, Ecological Indicators, 55 , https://doi.org/10.1016/j.ecolind.2015.03.002

Jakobsson, S. P. 1979. Outline of the petrology of Iceland, Jökull, 29, pp. 57-73.

Jakobsson, S. P., Jonasson, K. \& Sigurdsson, I. A. 2008. The tree igneous rock series of Iceland, Jökull, 58, pp. 117-138.

Kennedy, R. E., Yang, Z. \& Cohen, W. B. 2010. Detecting trends in forest disturbance and recovery using yearly Landsat time series: 1. LandTrendr - Temporal segmentation algorithms, Remote Sensing of Environment, 114, $\quad$ pp. 2897-2910. https://doi.org/10.1016/j.rse.2010.07.008

Klaučo, M., Gregorová, B., Stankov, U., Marković, V. \& Lemenkova, P. 2013a. Interpretation of Landscape Values, Typology and Quality Using Methods of Spatial Metrics for Ecological Planning, Environmental and Climate Technologies, October 14, 2013. Riga, Latvia. https://doi.org/10.13140/RG.2.2.23026.96963

Klaučo, M., Gregorová B., Stankov U., Marković V. \& Lemenkova P. 2013b. Determination of ecological significance based on geostatistical assessment: a case study from the Slovak Natura 2000 protected area, Open Geosciences, $\quad 5(1), \quad$ pp. 28-42. https://doi.org/10.2478/s13533-012-0120-0

Klaučo, M., Gregorová, B., Stankov, U., Marković, V. \& Lemenkova, P. 2014. Landscape metrics as indicator for ecological significance: assessment of Sitno Natura 2000 sites, Slovakia, Ecology and Environmental Protection, Minsk, Belarus, pp. 85-90. https://doi.org/10.6084/m9.figshare.7434200

Klaučo, M., Gregorová, B., Koleda, P., Stankov, U., Marković, V. \& Lemenkova, P. 2017. Land planning as a support for 
sustainable development based on tourism: A case study of Slovak Rural Region, Environmental Engineering and Management Journal, 2(16), pp. 449-458. https://doi.org/10.30638/eemj.2017.045

Kristinsson, H. 1986. A guide to the flowering plants and ferns of Iceland. Reykjavik: Mál og menning. https://doi.org/10.1111/j.1756-1051.1991.tb01794.x

Kristinsson, H. 2008. Íslenskt Plöntutal: Blómplöntur og byrkningar. Fjölrit náttúrufræðistofnunar, 51, pp. 1-58.

Krüger, J. 1994. Glacial processes, sediments, landforms and stratigraphy in the terminus region of Mýrdalsjökull, Iceland. Folia Geographica Danica, 21, pp. 1-233.

Lemenkova, P. 2011. Seagrass Mapping and Monitoring Along the Coasts of Crete, Greece. M.Sc. Thesis. University of Twente, Faculty of Earth Observation and Geoinformation (ITC), Enschede, Netherlands. https://doi.org/10.13140/RG.2.2.16945.22881

Lemenkova, P. 2013a. Monitoring Changes in Agricultural Landscapes of Central Europe, Hungary: Application of ILWIS GIS for Image Processing, Geoinformatics: Theoretical and Applied Aspects, 13-16 May, Ukraine, Kiev. https://doi.org/10.3997/2214-4609.20142479

Lemenkova P 2014a. Opportunities for Classes of Geography in the High School: the Use of 'CORINE' Project Data, Satellite Images and IDRISI GIS for Geovisualization. In: Perspectives for the Development of Higher Education. Belarus, Grodno, pp. 284-286. https://doi.org/10.6084/m9.figshare.7211933

Lemenkova P. 2014b. Detection of Vegetation Coverage in Urban Agglomeration of Brussels by NDVI Indicator Using eCognition Software and Remote Sensing Measurements. In: GIS and Remote Sensing, November 17-19, 2014, Tsaghkadzor, pp.

112-119. https://doi.org/10.6084/m9.figshare.743421

Lemenkova, P. 2015. Analysis of Landsat NDVI Time Series for Detecting Degradation of Vegetation, Geoecology and Sustainable Use of Mineral Resources. From Science to Practice, Belgorod, Russia, pp. 11-13. https://doi.org/10.6084/m9.figshare.7211795

Lemenkova, P. 2016. Using GIS for Monitoring Lacustrine Ecosystem: a Case Study of Laguna de Gallocanta, Spain. In Conference Proceedings Problems of the Environmental Landscape Planning, pp. 237-240. https://doi.org/10.6084/m9.figshare.7210229

Lemenkova, P. 2019a. Automatic Data Processing for Visualising Yap and Palau Trenches by Generic Mapping Tools, Cartographic Letters, 27(2), pp. 72-89. https://doi.org/10.6084/m9.figshare.11544048

Lemenkova, P. 2019b. AWK and GNU Octave Programming Languages Integrated with Generic Mapping Tools for Geomorphological Analysis, GeoScience Engineering, 65(4), pp. 1-22. https://doi.org/10.35180/gse-2019-0020

Lemenkova, P. 2019c. Statistical Analysis of the Mariana Trench Geomorphology Using R Programming Language, Geodesy and Cartography, 45(2), pp. 57-84. https://doi.org/10.3846/gac.2019.3785

Lemenkova, P. 2019d. Processing oceanographic data by Python libraries NumPy, SciPy and Pandas, Aquatic Research, 2(2), pp. 73-91.

Lemenkova, P. 2020a. GMT Based Comparative Geomorphological Analysis of the Vityaz and Vanuatu Trenches, Fiji Basin. Geodetski List, 74(1), pp. 19-39. https://doi.org/10.6084/m9.figshare.12249773
Lemenkova, P. 2020b. Variations in the bathymetry and bottom morphology of the Izu-Bonin Trench modelled by GMT. Bulletin of Geography. Physical Geography Series, 18(1), pp. 41-60. https://doi.org/10.2478/bgeo-2020-0004

Lemenkova, P. 2020c. Hyperspectral Vegetation Indices Calculated by Qgis Using Landsat Tm Image: a Case Study of Northern Iceland. Advanced Research in Life Sciences, 4(1), pp. 70-78. https://doi.org/10.2478/arls-2020-0021

Lemenkova, P. 2020d. SAGA GIS for information extraction on presence and conditions of vegetation of northern coast of Iceland based on the Landsat TM. Acta Biologica Marisiensis 3(2), pp. 10-21. https://doi.org/10.2478/abmj2020-0007

Lindh, P., Dahlin, T. \& Svensson, M. 2000. Comparisons Between Different Test Methods for Soil Stabilisation, in: GeoEng 2000, pp. 1-7.

Lindh P. 2001. Optimising binder blends for shallow stabilisation of fine-grained soils. In Proceedings of the Institution of Civil Engineers Ground Improvement, 5, pp. 23-34.

Lindh, P. \& Winter, M. G. 2003. Sample preparation effects on the compaction properties of Swedish fine-grained tills, Quarterly Journal of Engineering Geology and Hydrogeology, 36, pp. 321-330. https://doi.org/10.1144/1470-9236/03-018

Lindh P 2004. Compaction- and strength properties of stabilised and unstabilised fine-grained tills. $\mathrm{PhD}$ Thesis, Lund University, Lund. https://doi.org/10.13140/RG.2.1.1313.6481

Nagol, J. R., Sexton, J. O., Kim, D. H., Anand, A., Morton, D., Vermote, E. \& Townshend, J. R. 2015. Bidirectional effects in Landsat reflectance estimates: Is there a problem to solve? ISPRS Journal of Photogrammetry and Remote Sensing, 103, pp. 129-135. https://doi.org/10.1016/j.isprsjprs.2014.09.006

Qiu, S., Lin, Y., Shang, R., Zhang, J., Ma, L., Zhu, Z., Qiu, S., Lin, Y., Shang, R., Zhang, J., Ma, L. \& Zhu, Z. 2019. Making landsat time series consistent: evaluating and improving landsat analysis ready data, Remote Sensing, 11, pp. 51.

Robinson, Z. P., Fairchild, I. J. \& Russell, A. J. 2008. Hydrogeological implications of glacial landscape evolution at Skeiðarársandur, SE Iceland, Geomorphology, 97, pp. 218-236. https://doi.org/10.1016/j.geomorph.2007.02.044

Russell, A. J., Roberts, M. J., Fay, H., Marren, P. M., Cassidy, N. J., Tweed, F. S. \& Harris, T. 2006. Icelandic jökulhlaup impacts: implications for ice-sheet hydrology, sediment transfer and geomorphology, Geomorphology, 75, pp. 3364. https://doi.org/10.1016/j.geomorph.2005.05.018

Schenke, H. W. \& Lemenkova, P. 2008. Zur Frage der Meeresboden-Kartographie: Die Nutzung von AutoTrace Digitizer für die Vektorisierung der Bathymetrischen Daten in der Petschora-See, Hydrographische Nachrichten, 81, pp. 16-21. https://doi.org/10.6084/m9.figshare.7435538

Schowengerdt, R. 2007. Remote Sensing. Models and Methods for Image Processing, $3^{\text {rd }}$ ed., Schowengerdt, R. Academic Press.

Steindórsson, S. 1962. On the age and immigration of the Icelandic flora, Societas Scientiarum Islandica, 35, pp. 5155.

Suetova I. A., Ushakova L. A. \& Lemenkova P. 2005a. Geoinformation mapping of the Barents and Pechora Seas. Geography and Natural Resources, 4, pp. 138-142. https://doi.org/10.6084/m9.figshare.7435535 
Suetova I. A., Ushakova L. A. \& Lemenkova P. 2005b. Geoecological Mapping of the Barents Sea Using GIS, International Cartographic Conference, La Coruna Spain. https://doi.org/10.6084/m9.figshare.7435529

Thórhallsdóttir, T. E. 1996. Seasonal and annual dynamics of frozen ground in the central highland of Iceland, Arctic, Antarctic, and Alpine Research, 28, pp. 237-243. https://doi.org/10.2307/1551765

Tomaszkiewicz, M., Abou Najm, M., Beysens, D., Alameddine, I. \& El-Fadel, M. 2015. Dew as a sustainable non-conventional water resource: a critical review. Environmental Reviews, 23, pp. 425-442. https://doi.org/10.1139/er-2015-0035

Townshend, J. R., Masek, J. G., Huang, C., Vermote, E. F., Gao, F., Channan, S., Sexton, J. O., Feng, M., Narasimhan, R., Kim, D., Song, K., Song, D., Song, X. P., Noojipady, P., Tan, B., Hansen, M. C., Li, M. \& Wolfe, R. E. 2012. Global characterization and monitoring of forest cover using Landsat data: opportunities and challenges, International Journal of Digital Earth, 5, pp. 373-397. https://doi.org/10.1080/17538947.2012.713190

Valjarević, A., Djekić, T., Stevanović, V., Ivanović, R. \& Jandziković, B. 2018. GIS Numerical and remote sensing analyses of forest changes in the Toplica region for the period of 1953-2013. Applied Geographym 92, 131-139. https://doi.org/10.1016/j.apgeog.2018.01.016.

Valjarević A, Filipović D, Valjarević D, Milanović M, Milošević S., Živić, N. \& Lukić, T. 2020. GIS and remote sensing techniques for the estimation of dew volume in the Republic of Serbia. Meteorological Applications 27(3), e1930. https://doi.org/10.1002/met.1930

Vermote, E., Justice, C., Claverie, M. \& Franch, B. 2016. Preliminary analysis of the performance of the Landsat 8/OLI land surface reflectance product, Remote Sensing of Environment, $185, \quad$ pp. 46-56. https://doi.org/10.1016/j.rse.2016.04.008

Vuollekoski, H., Vogt, M., Sinclair, V. A., Duplissy, J., Järvinen, H., Kyrö, E.-M., Makkonen, R., Petäjä, T., Prisle, N. L., Räisänen, P., Sipilä, M., Ylhäisi, J. \& Kulmala, M. 2015. Estimates of global dew collection potential on artificial surfaces. Hydrology and Earth System Science, 19, pp. 601-613, https://doi.org/10.5194/hess-19-601-2015

Wan, N. 2015. Pesticides exposure modeling based on GIS and remote sensing land use data. Applied Geography, 56, pp. 99-106. https://doi.org/10.1016/j.apgeog.2014.11.012.
Wasowicz, P., Pasierbiński, A., Przedpelska-Wasowicz, E.M. \& Kristinsson, H. 2014. Distribution Patterns in the Native Vascular Flora of Iceland. PLoS ONE, 9(7), pp. E102916. https://doi.org/10.1371/journal.pone.0102916

Wessel, P. \& Smith, W. H. F. 1995. New version of the generic mapping tools released, Eos, Transactions American Geophysical Union, Washington, DC: American Geophysical Union, 329. https://doi.org/10.1029/95EO00198

Woodcock, C. E., Allen, R., Anderson, M., Belward, A., Bindschadler, R., Cohen, W., Gao, F., Goward, S. N., Helder, D., Helmer, E., Nemani, R., Oreopoulos, L., Schott, J., Thenkabail, P. S., Vermote, E. F., Vogelmann, J., Wulder, M. A. \& Wynne, R. 2008. Free access to Landsat imagery, Science, 320, pp. 1011.

Wulder, M. A., White, J. C., Loveland, T. R., Woodcock, C. E., Belward, A. S., Cohen, W. B., Fosnight, E. A., Shaw, J., Masek, J. G. \& Roy, D. P. 2016. The global Landsat archive: Status, consolidation, and direction, Remote Sensing of Environment, 185, pp. 271-283. https://doi.org/10.1016/j.rse.2015.11.032

Wulder, M. A., Loveland, T. R., Roy, D. P., Crawford, C. J., Masek, J. G., Woodcock, C. E., Allen, R. G., Anderson, M. C., Belward, A. S., Cohen, W. B., Dwyer, J., Erb, A., Gao, F., Griffiths, P., Helder, D., Hermosilla, T., Hipple, J. D., Hostert, P., Hughes, M. J., Huntington, J., Johnson, D. M., Kennedy, R., Kilic, A., Li, Z., Lymburner, L., McCorkel, J., Pahlevan, N., Scambos, T. A., Schaaf, C., Schott, J. R., Sheng, Y., Storey, J., Vermote, E., Vogelmann, J., White, J. C., \& Wynne, R. H. \& Zhu, Z. 2019. Current status of Landsat program, science, and applications, Remote Sensing of Environment, 225, pp. 127-147. https://doi.org/10.1016/j.rse.2019.02.015

Zhong, Y. \& Zhang, L. 2012. An Adaptive Artificial Immune Network for Supervised Classification of Multi/Hyperspectral Remote Sensing Imagery. IEEE Transactions on Geoscience and Remote Sensing 50(3), pp. 894-909. https://doi.org/10.1109/TGRS.2011.2162589

Zhu, Z., Wulder, M. A., Roy, D. P., Woodcock, C. E., Hansen, M. C., Radeloff, V. C., Healey, S. P., Schaaf, C., Hostert, P., Strobl, P., Pekel, J. F., Lymburner, L., Pahlevan, N. \& Scambos, T. A. 2019. Benefits of the free and open Landsat data policy, Remote Sensing of Environment, 224, pp. 382 385. https://doi.org/10.1016/j.rse.2019.02.016 